\title{
KEMAMPUAN KOMUNIKASI MATEMATIS SISWA SEKOLAH DASAR YANG BELAJAR MENGGUNAKAN PERMAINAN TRADISIONAL
}

\author{
Bagus Ardi Saputro \\ Sekolah Pascasarjana Universitas Pendidikan Indonesia \\ bagusardisaputro@student.upi.edu
}

\begin{abstract}
Abstrak
Tujuan penelitian ini adalah untuk mengetahui apakah dengan menggunakan permainan, kemampuan komunikasi matematis siswa lebih baik dari pada kemampuan komunikasi matematis siswa yang belajar secara konvensional. penelitian ini adalah penelitian kuasi eksperimen berdesain eksperimen perbandingan kelompok statik. Hasil penelitian menunjukkan bahwa kemampuan komunikasi matematis siswa yang belajar secara konvensional lebih baik dari pada kemampuan komunikasi matematis siswa yang belajar menggunakan permainan tradisional ditinjau secara keseluruhan, pada tiap level sekolah, dan pada tiap kemampuan awal matematis. Terdapat pengaruh interaksi antara level sekolah dan jenis pembelajaran terhadap kemampuan komunikasi matematis siswa. Tidak terdapat pengaruh interaksi antara jenis pembelajaran dengan kemampuan awal matematis terhadap kemampuan komunikasi matematis siswa.
\end{abstract}

Kata Kunci: Kemampuan komunikasi matematis, permainan tradisional

\section{A. Pendahuluan}

Selama ini dalam pelaksanaan pembelajaran matematika di Sekolah Dasar, siswa jarang sekali diberi kesempatan untuk mengkomunikasikan ideidenya. Sehingga siswa sulit memberikan penjelasan yang benar, jelas dan logis atas jawabannya (Rahmawati, 2013). Hal tersebut terus terulang di tingkat Sekolah Menangah Pertama dan Sekolah Menengah Atas. Qohar (2011) dan Agustyaningrum (2011) menemukan bahwa siswa kesulitan dan belum mampu mengkomunikasikan ide gagasannya secara terstruktur, walaupun sebenarnya ide dan gagasan, ada dalam pikiran mereka. $\mathrm{Hal}$ tersebut dikarenakan siswa kurang percaya diri dalam mengkomunikasikan gagasannya, siswa masih ragu - ragu dalam mengemukakan jawaban ketika ditanya guru (Agustyaningrum, 2011), siswa takut salah dan kurang terbiasa dalam mengungkapkan gagasannya (Qohar, 2011). Menurut Susilawati, Asnawati, \& Gunowibowo
(2013), siswa SMA juga masih mengalami kesulitan dalam merefleksikan benda - benda nyata, gambar, dan diagram ke dalam ide matematika, siswa kurang mampu dalam menjelaskan ide dan situasi menggunakan metode lisan, tulisan, grafik dan aljabar.

Setelah dilakukan observasi dan wawancara, diketahui bahwa pendekatan pembelajaran yang digunakan guru belum optimal dalam meningkatkan kemampuan komunikasi matematis, belum menggunakan media pembelajaran yang meningkatkan partisipasi aktif, pendekatan yang digunakan masih berpusat pada guru, sehingga siswa dipaksa menemukan sendiri makna dari perngertian matematika yang dipelajari (Marthen, 2010). Marthen (2010) dan Tandilling (2012) menemukan bahwa soal - soal yang diberikan, masing sebatas soal soal yang ada dalam buku teks, dan belum menggunakan soal - soal yang mengidentifikasi kemampuan komunikasi matematis siswa. Akibatnya siswa kurang semangat 
dalam belajar, siswa sangat pasif, siswa tidak mempunyai kesempatan untuk mencari konsep materi yang dipelajari, siswa sering mengeluh dan tidak mengerjakan soal - soal latihan, siswa kurang memahami materi, siswa cenderung diam dan lebih banyak mengobrol, siswa tidak bertanya ketika ditanya oleh guru (Susilawati, Asnawati

$\&$ Gunowibowo, 2013).

Sampai pada akhirnya, terjadi juga di perguruan tinggi. Fatimah (2013) menemukan bahwa mahasiswa cenderung menghafal materi perkuliahan dan tahap tahap penyelesaian pada contoh soal, mahasiswa kurang mampu menyelesaikan soal cerita, mahasiswa lebih senang jika diberikan soal berbentuk simbol dan angka - angka sehingga langsung tahu apa yang akan dicari tanpa harus menginterpretasikan soal terlebih dahulu, kemampuan mahasiswa dalam mengerjakan soal dalam bentuk simbol kurang diiringi dengan kemampuan mengkomunikasikan ide- ide matematis yang terkandung didalamnya, mahasiswa belum terbiasa menuangkan pemikirannya dalam bentuk lisan dan tulisan.

Oleh sebab itu perlu adanya inovasi dalam pembelajaran yang dapat memfasilitasi siswa dalam melakukan komunikasi matematis dari tingkat Sekolah Dasar. Zoltan Paul Dienes dalam buku Building Up Mathematics, Dienes (Hirstein, 2007) menjelaskan teorinya tentang enam fase belajar matematika: (1) bermain - main, (2) permainan, (3) pencarian bentuk serupa, (4) representasi, (5) simbolisasi, dan formalisasi. Permainan yang sudah lama populer di antara pada siswa akan digunakan sebagai laternatif pembelajaran tradisional. Karena menurut Soejadi dalam Rahmawati (2013) ketika mengaitkan pengalaman dunia nyata siswa dengan ide - ide matematika dalam pembelajaran di kelas, pembelajaran akan lebih bermakna. Inovasi tersebut sesuai dengan kurikulum KTSP yang menyarankan penggunaan media pembelajaran dalam upaya meningkatkan efektifitas proses pembelajaran (Depdiknas, 2006). Otiz (2003) juga menemukan bahwa pembelajaran dengan permainan berdampak positif terhadap kemampuan komunikasi matematis siswa. Sehingga

muncul pertanyaan; Apakah kemampuan komunikasi matematis siswa yang mendapat pembelajaran dengan permainan lebih baik dari pada kemampuan komunikasi matematis siswa yang mendapat pembelajaran konvensional ditinjau secara keseluruhan, pada tiap level sekolah, dan pada tiap kemampuan awal matematis? Adakah ada pengaruh interaksi antara jenis pembelajaran dan level sekolah terhadap pencapaian kemampuan komunikasi matematis? Adakah ada pengaruh interaksi antara jenis peembelajaran dan level kemampuan awal matematis terhadap pencapaian kemampuan komunikasi matematis?

\section{B. Kajian Teori}

\section{Kemampuan Komunikasi Matematis}

Kemampuan komunikasi matematis merupakan salah satu kemampuan yang dirumuskan dalam tujuan mata pelajaran matematika yaitu mengomunikasikan gagasan dengan simbol, tabel, diagram, atau media lain untuk memperjelas keadaan atau masalah (Depdiknas, 2006).Dalam pembelajaran matematika khusunya aspek bilangan, kemampuan komunikasi berkenaan dengan penggunaan simbol, ekpresi, dan kalimat matematika. Sumarmo (2007: 678) memberikan contoh seperti kita mengenalsimbol bilangan "2". Beliau menjelaskan simbol ini merupakan 
konsep yang abstrak, tidak tampak, tidak dapat diraba, atau tidak dapat diindra dan tidak termuat dalam benda yang bersangkutan secara langsung, namun maknanya tetap. Pada saat belajar bilangan simbol ini biasanya divisualisasikan melalui benda-benda konkrit. Siswa bisa mendapatkan enam dari aktivitas menghitung dan mengukur.

Contoh ekspresi adalah $15 \times \frac{2}{3}$. Sedangkan contoh kalimat yaitu $15 \times \frac{2}{3}=10$. Ketika belajar aritmetika dan aljabar, secara tidak langsung siswa sudah menggunakan matematika sebagai alat komunikasi.National Council of Teachers of Mathematics (NCTM) (1989: 78) mengemukakan bahwa siswa dapat mempelajari matematika sebagai alat komunikasi (mathematics as communication) sehingga siswa harus mampu 1) memodelkan situasi-situasi dengan menggunakan lisan, tulisan, kongkrit; gambar, grafik, dan metode-metode aljabar; 2) memikirkan dan menjelaskan pemikiran mereka sendiri tentang ide-ide dan situasi-situasi matematis; 3) mengembangkan pemahaman umum terhadap ide-ide matematis, termasuk peran dari definisi-definisi; 4) menggunakan keterampilan membaca, mendengarkan, dan melihat untuk menginterpretasikan, dan mengevalusi ide-ide matematis; 5) mendiskusikan ide-ide matematis dan membuat dugaan-dugaan dan alasan-alasan yang menyakinkan, dan; 6) menghargai nilai notasi matematika dan perannya dalam perkembangan ide-ide matematis.

Sebagai panduan untuk mengukur kemampuan komunikasi matematissiswa (NCTM, 1989: 214) menyarankan beberapa indikator yang digunakan adalah
1. Kemampuan menyatakan ide matematis dengan berbicara, menulis, demostrasi, dan menggambarkannya dalam bentuk visual,

2. Kemampuan memahami, menginterpretasikan, dan menilai ide matematis yang disajikan dalam tulisan, lisan, atau bentuk visual, dan

3. Kemampuan menggunakan kosakata/bahasa, notasi dan struktur matematika untuk menyajikan ide, menggambarkan hubungan dan pembuatan model.

Sumarmo (2007: 684) berpendapat bahwa kemampuan yang tergolong pada komunikasi matematis diantaranya adalah (a) menyatakan suatu situasi, gambar, diagram atau benda nyata ke dalam bahasa, simbol, idea, atau model matematis, (b) menjelaskan idea, situasi dan relasi matematika secara lisan atau tulisan, (c) mendengarkan, berdiskusi, dan menulis tentang matematika, (d) membaca dengan pemahaman suatu representasi matematika tertulis, (e) membuat konjektur, menyusun argumen, merumuskan definisi, dan generalisasi, (f) mengungkapkan kembali suatu uraian atau paragraf matematika dalam bahasa sendiri.

Wahyudin (2008: 534) berpendapat bahwa standar komunikasi program-program instruksional dari pra-TK hingga kelas 12 seharusnya memungkinkan semua siswa untuk (a) mengatur dan menggabungkan pemikiran matematis mereka lewat komunikasi, (b) mengkomunikasikan pemikiran matematis mereka secara koheren dan jelas pada teman-teman, guru dan orang lain, (c) menganalisis dan mengevaluasi pemikiran dan strategi-strategi metematis kepada orang lain, dan (d) menggunakan bahasa matematika untuk 
mengapresiasikan gagasan-gagasan matematis secara teliti.

Dalam penelitian ini dari ketiga pendapat tersebut, peneliti menggunakan lima aspek kemampuan komunikasi matematis yaitu 1) Memodel situasi-situasi menggunakan metode gambar, 2) Merefleksi dan menjelaskan pemikiran mereka sendiri tentang ide-ide dan situasi-situasi matematis, 3) Membangun pemahaman umum mengenai ide-ide matematis, termasuk peranan definisi-definisi, 4) Menggunakan keahlian membaca, menulis, memandang untuk menginterpretasi dan mengevaluasi ide-ide matematis, dan 5) Mendiskusikan ide-ide matematis serta membuat dugaan dan argumen yang meyakinkan. Kemampuan komunikasi tersebut relevan dengan kegiatan permainan yang akan dilakukan dan operasi pada pecahan.

\section{Permainan Tradisional}

Permainan dalam penelitian ini adalah permainan yang dirancang berdasarkan konsep operasi pada pecahan, yang relevan dengan teori Dienes, yang terkait dengan kemampuan penalaran dan komunikasi matematis, dan yang disesuaikan dengan kondisi lingkungan siswa yaitu secara sosial ekonomi.

Untuk membuat permainan yang tepat dengan konsep operasi pada pecahan. Maka perlu ada referensi tentang konsep operasi pada pecahan secara algoritmik. Aturan algoritmik tentang konsep operasi pada pecahan didapatkan dari beberapa sumber seperti buku aljabar, kamus, dan jurnal.

Dari algoritmik tersebut ditelaah makna aturannya yang direlevansikan dengan aktivitasaktivitas yang mungkin dapat dilakukan siswa. Makna dari algoritmik operasi pada pecahan adalah proses membagi dan proses membandingkan. Proses membagi didapat dari pemaknaan kalimat pecahan merupakan hasil bagi. Sedangkan proses membandingkan didapat dari pemaknaan kalimat pecahan merupakan perbandingan.

Tahap selanjutnya adalah membuat aktivitas yang relevan dengan aturan algotima operasi pada pecahan. Menentukan suatu aktivitas tidak akan terlepas dari menentukan alat yang digunakan pada aktivitas tersebut. Untuk itu perlu dilihat kondisi lingkungan, sosial, ekonomi siswa sebagai pelaku permainan. Sehingga ditentukan alat yang digunakan untuk permainan pecahan sebagai hasil bagi adalah lidi, dan lilin mainan atau tanah liat. Sedangkan alat yang digunakan untuk permainan pecahan sebagai proses perbandingan adalah ranting, daun, biji dan batu kerikil. Alat-alat ini mudah didapatkan dan mempunyai sifat yang mudah dimanipulasi. Artinya alat-alat tersebut mempunyai sifat sesuai dengan aturan operasi pada pecahan. Seperti lidi mempunyai sifat panjang, mudah dipotong untuk mendapatkan hasil baginya. Lilin mainan atau tanah liat jika dibentuk akan mempunyai sifat luas permukaan, mudah dipotong atau dibelah untuk mendapatkan hasil bagi dan dapat dibandingkan. Kemudian sifat yang dipunyai oleh ranting, daun, biji dan batu kerikil adalah jumlahnya yang banyak tersedia di alam. Sifat ini dipilih karena permainan pecahan sebagai perbandingan merupakan aktivitas permainan yang memanipulasi kuantitas suatu benda.

Bagian terpenting dari perancangan permainan adalah menyusun aktivitas yang berkesinambungan, artinya setiap aktivitas yang dilakukan dengan alatalat tersebut harus terkait satu sama lain. Aktivitas yang disusun sesuai dengan makna dari setiap operasi hitung pada pecahan. Dalam 
penelitian ini, permainan dibagi kedalam tahap-tahap belajar matematika menurt Zoltan Paul Dienes tekait dengan konsep pecahan

\section{1) Bermain-main}

Anak-anak akan di hadapkan pada sebuah aneka macam alat permainan seperti kelereng, uang, kartu, karet gelang, malam atau benda-benda yang disediakan alam seperti daun, ranting, lidi, dan tanah liat. Mereka akan dibebaskan untuk memainkannya. Mereka dibebaskan untuk berekspresi, memanipulasi benda-benda tersebut sesuai dengan keinginan mereka. Mungkin anak akan bermain kelereng, membuat suatu bentuk dari malam atau tanah liat, memotong lidi, ranting, serta membuat aneka hiasan dari daun.

\section{2) Permainan}

Sebuah keteraturan akan muncul, dan anak akan segera menyadarinya. Bahwa beberapa aktivitas mereka akan sangat mengasikkan bila disertai dengan aturan. Pada saat anak mulai menggunakan aturan yang mereka buat, guru akan membimbing mereka untuk menemukan/membuat dan melakukan aturan yang relevan dengan konsep pecahan dan operasinya. Beberapa aktivitas yang relevan dengan konsep pecahan adalah memotong dan mengambil (lidi, ranting, daun), berbagi kelereng dengan teman yang lainnya, membuat aneka bentuk tiruan dari malam atau tanah liat, atau mulai memainkan pasar-pasaran (aneka jual beli). Beberapa kemungkinan dari kegiatan yang akan dilakukan anak berusaha guru arahkan, sehingga ada beberapa kemungkinan yang sudah guru perkirakan. Kegiatan ini merupakan permainan yang aturannya relevan dengan konsep pecahan.

\section{3) Mencari Kesamaan Bentuk}

Saatnya untuk memperjelas aktivitas yang sudah dilakukan, yaitu memperjelas apakah ada kaitan/kesamaan bentuk dari aturanaturan yang sudah dimainkan. Sehingga guru dapat membimbing siswa untuk membuat sebuah tabel untuk mencatat kesamaan aktivitas dari permainan.

\section{4) Representasi}

Setelah diketahui bahwa permainan yang sudah dilakukan berkenaan dengan konsep pecahan, guru akan mendorong siswa untuk menempatkan pecahan-pecahan itu pada garis bilangan.

\section{5) Simbolisasi}

Pecahan-pecahan tersebut sudah mulai disimbolkan dengan simbol yang formal. Seperti aktivitas membagi dua kemudian mengambil satu artinya $1 / 2$. Menggabungkan hasil dari pengambilan artinya penjumlahan pada pecahan. Menyingkirkan satu bagian dengan bagian yang lain artinya pengurangan pada pecahan. Melakukan membagi, mengambil, dilanjutkan membagi lagi terus mengambil pada satu benda merupakan perkalian pada pecahan. Menemukan berapa banyak bagian di dalam bagian yang lain merupakan pembagian pecahan. Guru akan memberikan aneka alat permainan beserta aturannya. Anak akan melakukan permainan dengan menggunakan benda-benda yang merepresentasikan pecahan seperti kartu bilangan pecahan, bentukbentuk geometri yang merepresentasikan pecahan.

\section{6) Formalisasi}

Setelah anak sudah mulai menyadari adanya keteraturan dalam operasi pecahan. Mereka dibimbing untuk menemukan dan memahami keteraturan tersebut seperti komutatif, asosiatif pada perkalian dan penjumlahan. Yang akhirnya siswa dapat menyelesaikan permasalahan yang berhubungan dengan konsep pecahan dan aturan operasinya. 


\section{Metode Penelitian}

Metodologi yang digunakan adalah kuasi eksperimen berdesain eksperimen perbandingan kelompok statik, yaitu:

X_-_o_(Ruseffendi, 2005)

Dengan catatan: $X$ adalah pembelajaran dengan permainan. $O$ adalah tes kemampuan komunikasi matematis.

Populasinya adalah siswa

kelas V Sekolah Dasar di Kecamatan Bulakamba Kabupaten

Brebes. Dari tiap level SD (tinggi, sedang, rendah) diambil sampel satu SD secara acak. Kemudian kelas $\mathrm{V}$ pada tiap SD dibagi menjadi dua kelas ditetapkan satu sebagai kelas eksperimen, yang satunya lagi sebagai kelas kontrol. Instruman yang digunakan adalah tes kemampuan komunikasi matematis dalam bentuk uraian dan pilihan banyak.

\section{Hasil dan Pembahasan}

Data hasil skor kemampuan komunikasi matematis dapat di lihat pada Tabel 1 di bawah ini.

Tabel 1. Deskripsi Skor Kemampuan Komunikasi Matematis

\begin{tabular}{|c|c|c|c|c|c|c|c|c|c|}
\hline \multirow{3}{*}{ KAM } & \multirow{3}{*}{ Statistik } & \multicolumn{8}{|c|}{ Pembelajaran } \\
\hline & & \multicolumn{4}{|c|}{ Permainan } & \multicolumn{4}{|c|}{ Konvensional } \\
\hline & & $\begin{array}{c}\text { Sek. } \\
\text { Tinggi }\end{array}$ & $\begin{array}{c}\text { Sek. } \\
\text { Sedang }\end{array}$ & $\begin{array}{c}\text { Sek. } \\
\text { Rendah }\end{array}$ & Total & $\begin{array}{c}\text { Sek. } \\
\text { Tinggi }\end{array}$ & $\begin{array}{c}\text { Sek. } \\
\text { Sedang }\end{array}$ & $\begin{array}{c}\text { Sek. } \\
\text { Rendah }\end{array}$ & Total \\
\hline \multirow{3}{*}{ Tinggi } & $\bar{X}$ & 2.57 & 1.75 & 1.67 & 2.05 & 2.80 & 2.45 & 2.20 & 2.48 \\
\hline & $S D$ & 1.51 & 0.46 & 0.58 & 1.05 & 1.30 & 0.82 & 0.45 & 0.87 \\
\hline & $N$ & 7 & 8 & 3 & 18 & 5 & 11 & 5 & 21 \\
\hline \multirow{3}{*}{ Sedang } & $\bar{X}$ & 1.31 & 1.90 & 2.20 & 1.62 & 2.29 & 2.33 & 2.43 & 2.33 \\
\hline & $S D$ & 0.88 & 0.99 & 0.84 & 0.95 & 0.77 & 0.82 & 0.79 & 0.75 \\
\hline & $N$ & 19 & 10 & 5 & 34 & 17 & 6 & 7 & 30 \\
\hline \multirow{3}{*}{ Rendah } & $\bar{X}$ & 1.29 & 1.83 & 1.71 & 1.47 & 2.29 & 2.33 & 1.67 & 2.15 \\
\hline & $S D$ & 0.78 & 1.83 & 1.71 & 0.82 & 0.91 & 1.15 & 0.52 & 0.88 \\
\hline & $N$ & 21 & 6 & 7 & 34 & 17 & 3 & 6 & 26 \\
\hline \multirow{3}{*}{ Total } & $\bar{X}$ & 1.49 & 1.83 & 1.87 & 1.65 & 2.36 & 2.40 & 2.11 & 2.31 \\
\hline & $S D$ & 1.04 & 0.76 & 0.83 & 0.94 & 0.90 & 0.82 & 0.68 & 0.83 \\
\hline & $N$ & 47 & 24 & 15 & 86 & 39 & 20 & 18 & 77 \\
\hline \multicolumn{10}{|c|}{ Skor Maksimum Ideal = 5} \\
\hline
\end{tabular}

Setelah data pada Tabel 1 dianalisis dengan uji $t$ dan MannWhitney dihasilkan kesimpulan bahwa, kemampuan komunikasi matematis siswa yang belajar secara konvensional lebih baik dari pada kemampuan komunikasi matematis siswa yang belajar menggunakan permainan tradisional, terjadi pada KAM sedang dan KAM rendah di sekolah level tinggi, pada KAM tinggi di sekolah level sedang. 


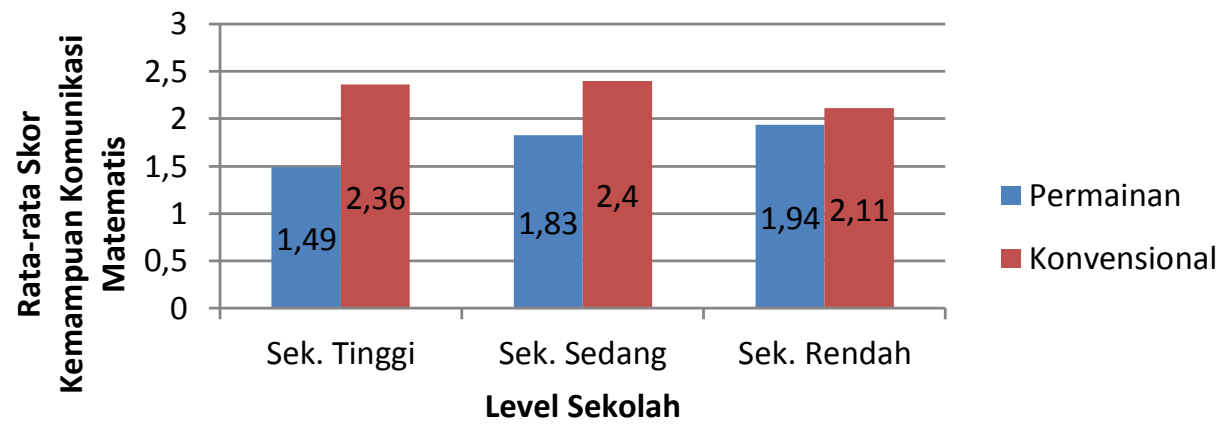

Gambar 1. Rerata Skor Kemampuan Komunikasi Matematis Berdasarkan Level Sekolah

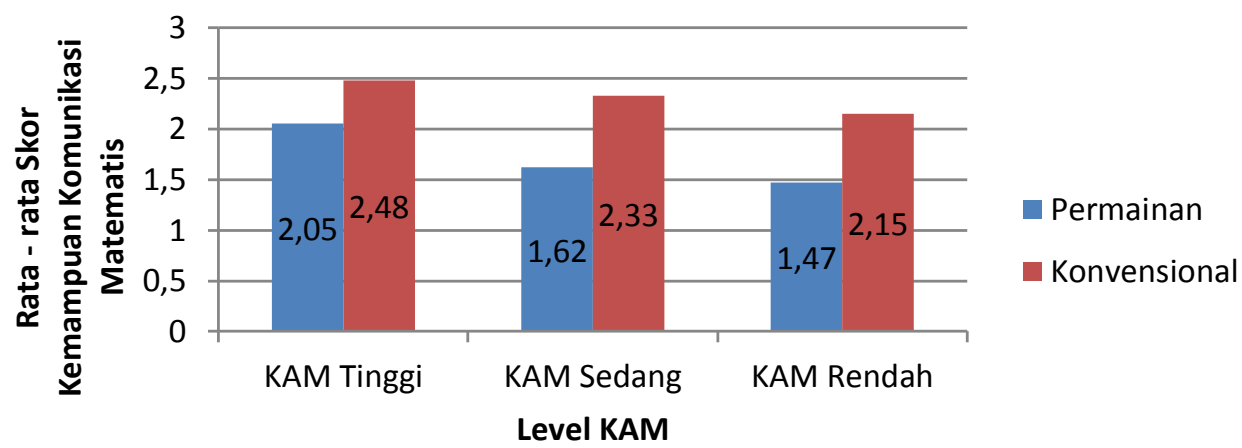

Gambar 2. Rerata Skor Kemampuan Komunikasi Matematis Berdasarkan Level KAM

Berdasarkan level sekolah, pada sekolah level tinggi dan sekolah level sedang, kemampuan komunikasi matematis siswa yang belajar secara konvensional lebih baik dari pada siswa yang belajar menggunakan permainan tradisional. Sedangkan pada sekolah level rendah, tidak ada perbedaan yang berarti antar kemampuan komunikasi matematis siswa yang

belajar secara konvensional dengan kemampuan komunikasi matematis siswa yang belajar dengan permainan. Secara keseluruhan, kemampuan komunikasi matematis siswa yang belajar secara konvensional lebih baik dari pada kemampuan komunikasi matematis siswa yang belajar dengan permainan tradisional.

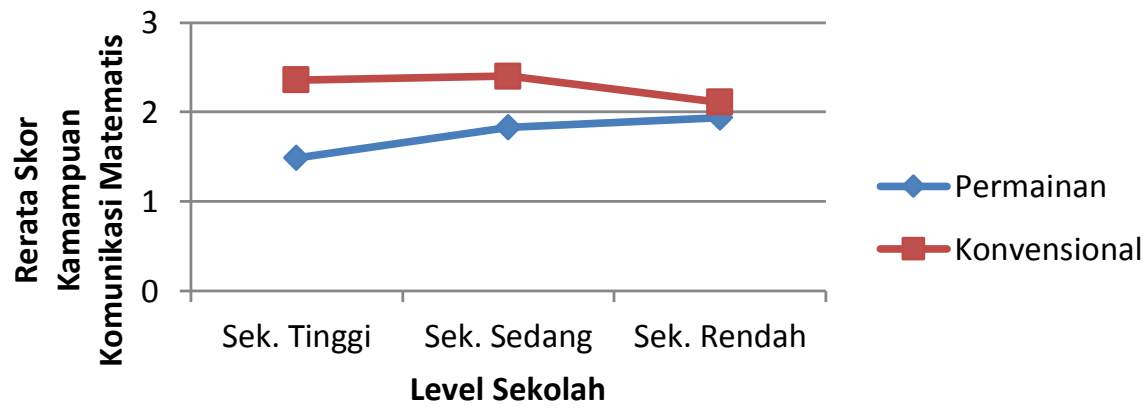

Gambar 3. Interaksi antara Level Sekolah dan Model Pembelajaran terhadap Kemampuan Komunikasi Matematis 


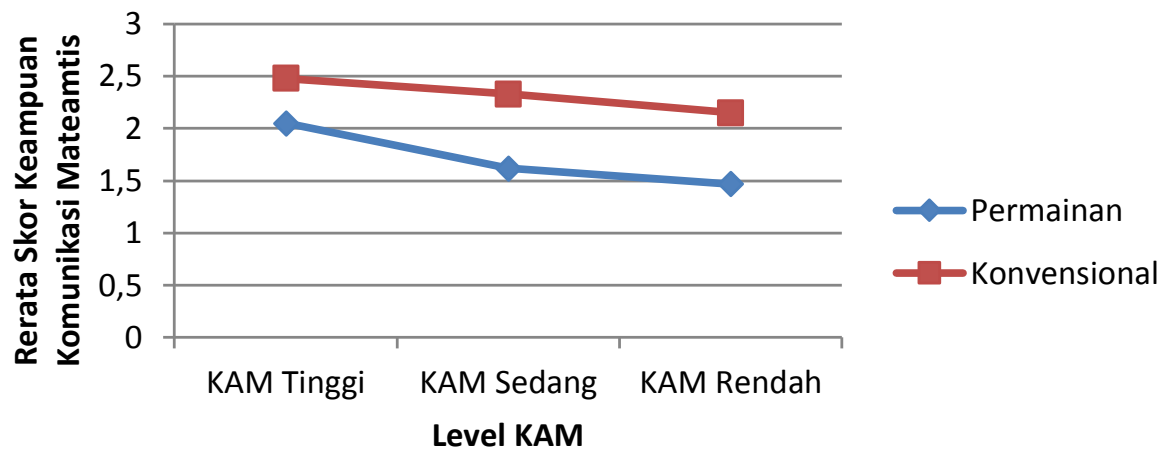

Gambar 4. Interaksi Antara Level KAM dan Model Pembelajaran Terhadap Kemampuan Komunikasi Matematis

\begin{abstract}
Dari gambar 3, dapat disimpulkan bahwa terdapat pengaruh interaksi antara level sekolah dan jenis pembelajaran terhadap kemampuan komunikasi matematis siswa. Selanjutnya dari gambar 4, dapat disimpulkan bahwa tidak terdapat pengaruh interaksi antar kemampuan awal matematis dan jenis pembelajaran terhadap kemampuan komunikasi matematis siswa.
\end{abstract}

Berdasarkan level sekolah, walaupun uji statistika menunjukkan bahwa kemampuan komunikasi matematis siswa yang belajar secara konvensional lebih baik dari pada yang belajar menggunakan permainan tradisional. Tetapi jika terlihat bahwa kemampuan komunikasi matematis siswa sekolah level rendah adalah yang tertinggi dibandingkan siswa di sekolah level sedang dan sekolah level tinggi. Hal tersebut memberikan isyarat bahwa, permainan tradisional berpengaruh terhadap kemampuan komunikasi matematis siswa pada sekolah level rendah. Interpretasi ini memberikan peluang kepada guru - guru yang mengajar di sekolah dasar level rendah untuk menggunakan permainan tradisional guna memfasilitasi kemampuan komunikasi matematis siswa.

Berbeda halnya dengan hasil kamampuan komunikasi matematis siswa berdasarkan level kemampuan awal matematis siswa. Kurva kemampuan komunikasi matematis siswa yang belajar menggunakan permainan tradisional memperlihatkan bahwa kemampuan awal matematis siswa yang tinggi justru lebih difasilitasi dengan permainan tradisional dibandingkan siswa yang mempunyai kemampuan awal matematis sedang dan rendah. Hasil interpretasi menimbulkan beberapa asumsi, dugaan dan pertanyaan seperti mengapa jika berdasarkan kemampuan awal matematis, siswa yang mempunyai KAM tinggi cenderung memiliki kemampuan komunikasi matematis lebih baik padahal jika berdasarkan level sekolah, kemampuan komunikasi matematis siswa lebih berkembang di sekolah level rendah. Sehingga perlu adanya penelitian selanjutnya yang menyelidiki lebih dalam terhadap kemampuan komunikasi matematis siswa berdasarkan kemampuan awal matematis siswa.

\section{E. Kesimpulan}

Berdasarkan hasil penelitian diperoleh kesimpulan bahwa, kemampuan komunikasi matematis siswa yang belajar secara konvensional lebih baik dari pada kemampuan komunikasi matematis siswa yang belajar menggunakan permainan tradisional ditinjau secara keseluruhan, pada tiap level 
sekolah, dan pada tiap kemampuan awal matematis. Terdapat pengaruh interaksi antara level sekolah dan jenis pembelajaran terhadap kemampuan komunikasi matematis

\section{Daftar Rujukan}

Agustyaningrum, $\quad$ N., $\quad$ (2011). Implementasi Model Pembelajaran Learning Cycle 5E untuk Meningkatkan Kemampuan Komunikasi Matematis Siswa Kelas IX B SMP Negeri 2 Sleman. Matematika dan Pedidikan Karakter dalam Pembelajaran.

Depdiknas. (2006). Kurikulum Tingkat Satuan Pendidikan. Jakarta: Depdiknas.

Fatimah, F. (2013). Kemampuan Komunikasi Matematis dalam Pembelajaran Statistika Elementer melalui Problem Based-Learning. Cakrawala Pendidikan, 5(2).

Hirstein, J. (2007). The Impact of Zoltan Dienes on Mathematics Teaching in The United States. Dalam The Montana Mathematics Enthusiast, Montana Council of Teachers of Mathematics [Online], Monograph 2, hal. 169-172.

Marthen, T. (2010). Pembelajaran Melalui Pendekatan REACT Meningkatkan Kemampuan Matematis Siswa SMP. Jurnal Penelitian Pendidikan, 11(2), 11-20.

National Council of Teachers of Mathematics. Commission on Standards for School Mathematics. (1989). Curriculum Evaluation Standards for School Mathematics. Reston, V.A: siswa. Tidak terdapat pengaruh interaksi antara jenis pembelajaran dengan kemampuan awal matematis terhadap kemampuan komunikasi matematis siswa.

Rahmawati, F. (2013). Pengaruh Pendekatan Pendidikan Realistik Matematika dalam Meningkatkan Kemampuan Komunikasi Matematis Siswa Sekolah Dasar. Prosiding SEMIRATA 2013, 1(1).

Ruseffendi, E.T. (2005). Dasar-dasar Penelitian Pendidikan \& Bidang Non-eksakta Lainnya. Bandung: Tarsito.

Sumarmo, U. (2007). Pembelajaran Matematika. Dalam Rujukan Filsafat, Teori, dan Praksis IImu Pendidikan. Editor Natawidjaya, et al. Bandung: Universitas Pendidikan Indonesia Press.

Susilawati, E., Asnawati, R., \& Gunowibowo, P. (2013). Pengaruh Pembelajaran Dengan Strategi Thinking Aloud Pair Problem Solving Terhadap Kemampuan Komunikasi Matematis Siswa. Jurnal Pendidikan Matematika Unila, 1(4).

Tandilling,

E. (2012). Pengembangan Instrumen Untuk Mengukur Kemampuan Komunikasi Matematik, Pemahaman Matematik, Dan Self Regulated Learning Siswa Dalam Pembelajaran Matematika Di Sekolah Menengah Atas. Jurnal Penelitian Pendidikan, 13(1), 24-31.

Ortiz, E. (2003). Research Findings from Games Involving Basic Fact Operations and Algebraic Thinking at a PDS. The ERIC Clearinghouse on Teaching and Teacher Education. 
Washington, D.C. (Nonrefereed.).

Qohar, A. (2011). Pengembangan Instrumen Komunikasi Matematis untuk Siswa SMP. Tersedia: http://eprints. uny. ac. id. (diakses pada tanggal 05 November 2013).

Wahyudin. (2008). Pembelajaran Matematika dan Pemecahan Masalah. Bandung: Mandiri.

\section{Riwayat Penulis}

Bagus Ardi Saputro adalah dosen Universitas PGRI Semarang, mendapatkan gelar magister dari Sekolah Pascasarjana Universitas Pendidikan Indonesia tahun 2011. Sekarang sedang studi doktoral di kampus yang sama sejak tahun 2015. Alamat yang dapat dihubungi Desa. Banjaratma Rt. 06/ 08 Kec. Bulakamba Kab. Brebes 